\title{
DZIEDZICTWO GRECKIE W JĘZYKU RUMUŃSKIM I ARUMUŃSKIM
}

\author{
TOMASZ KLIMKOWSKI
}

\begin{abstract}
Tomasz Klimkowski, Dziedzictwo greckie $w$ języku rumuńskim i rumuńskim (Greek heritage in Romanian and Aromanian).
\end{abstract}

Balcanica Posnaniensia. Acta et studia, XIX, Poznań 2012, Wydawnictwo Instytutu Historii UAM, pp. 19-30, ISBN 978-83-63-047-17-7, ISSN 0239-4278. Polish text with a summary in English.

Tomasz Klimkowski, Uniwersytet im. Adama Mickiewicza, Instytut Filologii Romańskiej, Aleje Niepodległości 4, 61-874 Poznań, Polska - Poland.

Romańszczyzna bałkańska, niegdyś zapewne dość jednolita', rozpada się obecnie na cztery odrębne etnolekty, których wzajemna niezrozumiałość wynika w dużej mierze z różnego pochodzenia używanych w nich zapożyczeń, tym bardziej że stanowią one często znaczną część ich leksyki, również podstawowej. Wspólne wszystkim są jedynie substrat paleobałkański, adstrat średniogrecki i superstrat starosłowiański, decydujące o ich odrębności na tle pozostałych języków romańskich, podczas gdy późniejsze warstwy zapożyczeń mają już charakter indywidualny, co oczywiście uwarunkowane jest czynnikami historycznymi i geograficznymi. I tak, specyfikę rumuńskiego stanowią: adstrat węgierski, cerkiewnosłowiański, średnio- i nowogrecki, turecki, a później francuski i łaciński, istrowołoskiego - chorwacki i włoski, meglenowołoskiego - bułgarsko-macedoński, średnio- i nowogrecki oraz turecki, a arumuńskiego - bułgarsko-macedoński, albański, średnio- i nowogrecki oraz turecki. Jak widać z powyższego wyliczenia, o wpływie greckim można mówić zarówno w odniesieniu do okresu hipotetycznej bałkanoromańskiej wspólnoty językowej, jak i do epoki nowożytnej. I faktycznie - jeśli traktować romańszczyznę romańską całościowo - wpływ grecki wykazuje największą ze wszystkich wpływów obcych rozpiętość

${ }^{1}$ Termin język (pra)batkanoromański (w nauce rumuńskiej najczęściej protoromână lub româna comună, czyli 'prarumuński'), odnosi się do hipotetycznego języka, który kontynuuje bałkańską odmianę łaciny i z którego wywodzą się współczesne romańskie języki Bałkanów. Bałkanoromańska wspólnota językowa przypada - w dużym przybliżeniu - na II połowę I tysiąclecia. 
czasową, mimo że dla poszczególnych etnolektów czas ten ulega często znacznemu skróceniu. Stanowiska skrajne zajmują arumuński i istrowołoski. Pierwszy z nich rozwija się pod wpływem greki od okresu prabałkanoromańskiego, zaś apogeum jej oddziaływania przypada na ostatnie wieki, a może nawet tysiąclecie. Wpływ grecki na istrowołoski ogranicza się z kolei do czasów wspólnoty bałkanoromańskiej.

Paradoksalnie wpływ greki na romańszczyznę bałkańską jest w pewnym sensie starszy od niej samej, ponieważ łacina, z której ta się wywodzi, zawiera szereg zapożyczeń ze starogreckiego. Reasumując - greka oddziaływała na łacinę, a później na romańszczyznę bałkańską (jeszcze jednolitą lub już podzieloną) we wszystkich okresach swojego rozwoju: jako greka starożytna (język starogrecki), greka bizantyńska (język średniogrecki) i greka nowożytna (język nowogrecki).

Liczbę hellenizmów w łacinie ocenia się na ponad $400^{2}$. Należą one do szeroko pojętego słownictwa technicznego i abstrakcyjnego. W dużej części pochodzenia greckiego jest również łacińska terminologia chrześcijańska. Wiele z tych terminów zachowało się w językach romańskich, np. gr. $\chi \dot{\alpha} \rho \tau \eta \varsigma>$ łac. charta > fr. charte 'karta', hiszp., port., wł. carta 'list', rum. carte 'list, książka', gr. ’’ $\gamma \gamma \varepsilon \lambda \varsigma_{\varsigma}>$ łac. angelus $>$ fr. ange, hiszp. ángel, port. anjo, wł. angelo, rum. înger 'anioł'.

Wpływ greki bizantyńskiej na jednolitą jeszcze łacinę bałkańską czy późniejszą romańszczyznę bałkańską jest trudniejszy do ustalenia. Kryterium datowania danego grecyzmu na ten okres jest jego występowanie we wszystkich czterech etnolektach bałkanoromańskich, co oznaczałoby jego zapożyczenie przez ich wspólnego przodka i późniejszą kontynuację w nich wszystkich z osobna. Brak danego wyrazu w jednym $\mathrm{z}$ tych języków (na ogół w istrowołoskim) podważałby wówczas tak wczesną datację, a wtedy jego obecność w pozostałych należałoby tłumaczyć niezależnymi zapożyczeniami (choć $\mathrm{z}$ drugiej strony wyraz ten mógł przecież zaniknąć w jednym $\mathrm{z}$ języków). Innymi słowy, datowanie danego zapożyczenia na ten okres pewne jest jedynie w przypadku wyrazów zachowanych na całym obszarze bałkanoromańskim. Ten warunek spełniają właściwie tylko 2 wyrazy: rum., istr., megl. mic, arum. njic

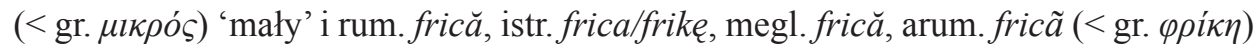
'strach's.

Drugie kryterium ma charakter fonetyczny - jeśli dane zapożyczenie wykazuje cechy fonetyki późnej greki starożytnej lub wczesnej greki bizantyńskiej, można je datować na okres bałkanoromański. Forma fonetyczna arumuńska (również meglenowołoska) jest tu często niemiarodajna, ponieważ ze względu na stały kontakt arumuńskiego z greką postać fonetyczna danego wyrazu mogła się na bieżąco dostosowywać do jego aktualnego greckiego brzmienia, zaciemniając w ten sposób rzeczywisty czas zapożyczenia. Ze względu na to kryterium za pożyczki z tego okresu należałoby uznać m. in. wyrazy: rum. proaspăt, megl., arum. proaspit (< gr. $\pi \rho o ́ \sigma \varphi \alpha \tau o \varsigma)$ 'świe-

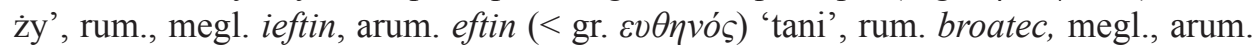

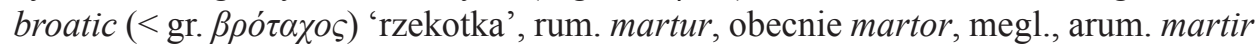

\footnotetext{
${ }^{2}$ Istoria limbii române, t. I, Bucureşti 1965, s. 49.

${ }^{3}$ Nadmieńmy, że zapożyczenie to występuje również w albańskim (frikë).
} 


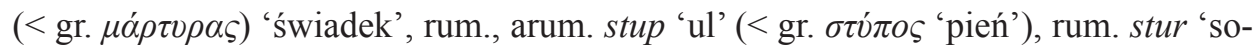
pel', arum. stur 'słup' (< gr. $\sigma \tau \tilde{v} \lambda o \varsigma$ 'kolumna'). W powyższych przykładach $\varphi, \theta, \chi$, $\beta$ i $v$ oddane są jako [p], [t], [k], [b] i [u], które odzwierciedlają wymowę starogrec$\mathrm{ka}\left[\mathrm{p}^{\mathrm{h}}\right],\left[\mathrm{t}^{\mathrm{h}}\right],\left[\mathrm{k}^{\mathrm{h}}\right],[\mathrm{b}] \mathrm{i}[\mathrm{y}]$, a nie późniejszą [f], [0] (tę przejęliby Arumuni greccy), $[\mathrm{x}]$, [v] i [i].

Na podstawie obu kryteriów można wyróżnić nie więcej niż kilkanaście wyrazów, z których jedynie kilka jest faktycznie w użyciu. Znacznie liczniejsze są zapożyczenia z późniejszych wieków, już o charakterze indywidualnym, tzn. występujące w poszczególnych językach bałkanoromańskich (choć w zasadzie tylko w trzech: rumuńskim, arumuńskim i w dużo mniejszym stopniu w meglenowołoskim, który z tego względu nie będzie przedmiotem niniejszej analizy).

Greka bizantyńska oddziaływała na język starorumuński dwiema drogami: bezpośrednio i za pośrednictwem cerkiewnosłowiańskim. Wpływ ten przybrał na sile między XIII i XV w., tzn. w pierwszych wiekach istnienia hospodarstw Mołdawii i Wołoszczyzny. Z czasów bizantyńskich pochodzą również greckie z pochodzenia nazwy nadczarnomorskich i naddunajskich miast takich jak: Constanța, Mangalia, Sulina, Giurgiu czy Calafat ${ }^{4}$.

Na prawie 280 zapożyczeń z greki bizantyńskiej jedynie około 20 ma charak-

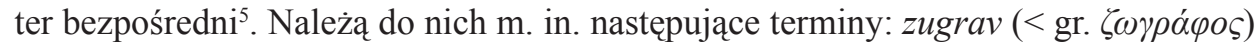
'malarz', folos (< gr. ó $\varphi \varepsilon \lambda o \varsigma)$ 'korzyść', prisos (< gr. $\pi \varepsilon \rho \imath \sigma \sigma o ́ \varsigma)$ 'nadmiar', arvu$n \breve{a}(<$ gr. $\alpha \rho \rho \alpha \beta \omega ́ v)$ 'zadatek', catarg (< gr. $\kappa \alpha \tau \dot{\alpha} \rho \tau \imath)$ 'maszt', cort (< gr. $\kappa o ́ \rho \tau \imath)$ 'namiot', plapumă (< gr. $\pi \alpha \dot{\pi} \lambda \omega \mu \alpha)$ 'kołdra', trandafir (< gr. $\tau \rho \imath \alpha \nu \tau \dot{\alpha} \varphi v \lambda \lambda o v)$ 'róża', zo-

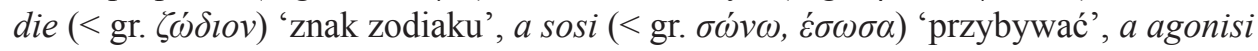
(< gr. $\left.\alpha \gamma \omega v i \zeta{ }_{0} \mu \alpha l, \alpha \gamma \omega ́ v \imath \sigma \alpha\right)$ 'dorabiać się’.

Ponad 10-krotnie więcej zapożyczeń trafiło do rumuńskiego przez cerkiewnosło-

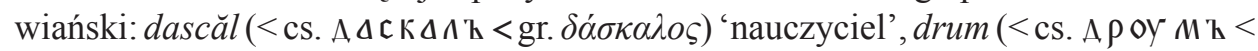

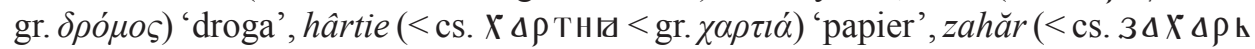

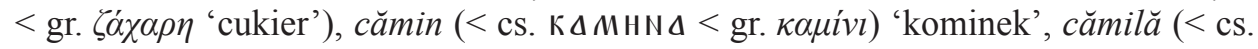

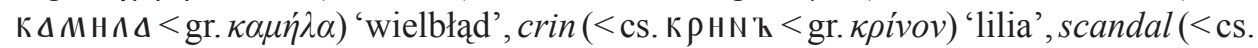

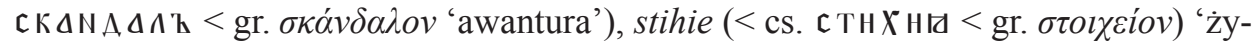
wioł'. Ze względu na funkcję, jaką pełnił cerkiewnosłowiański w państwach rumuńskich, spora część tych zapożyczeń to terminologia polityczno-administracyjna: logo-

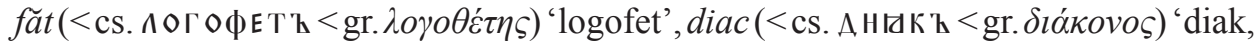

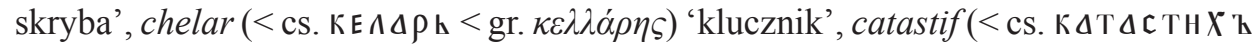

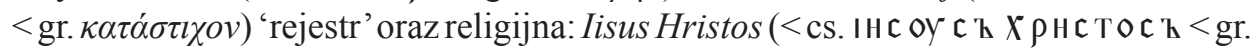

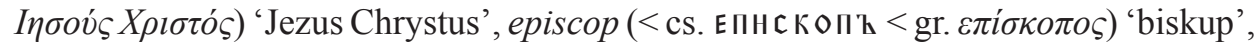

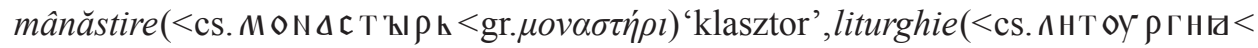

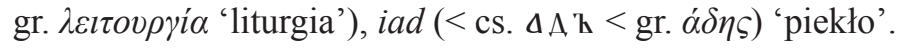

${ }^{4}$ H. Mihăescu, Influența grecească asupra limbii române pînă în secolul al XV-lea, Bucureşti 1966, s. 127.

${ }^{5}$ H. Mihăescu, op. cit., s. 188. 
Apogeum wpływów greckich na rumuński przypada na XVIII w., a dokładniej na lata 1711-1821, tzw. epokę fanariocką. L. Gáldi szacuje liczbę zapożyczeń nowogreckich w rumuńskim epoki fanariockiej na 1200 jednostek leksykalnych ${ }^{6}$. Ograniczymy się tylko do podania przykładów tych zapożyczeń, które wytrzymały próbę czasu, jako że ten okazał się dla nich bardzo niełaskawy - w ramach reromanizacji, która nastapiła bezpośrednio po czasach fanariockich, nie tylko powstrzymano napływ nowych zapożyczeń, ale również wyeliminowano ogromną większość dotychczasowych, na równi zresztą z turcyzmami $\mathrm{i}-\mathrm{w}$ mniejszym stopniu - slawizmami: fran-

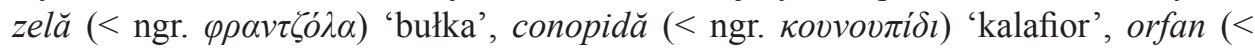

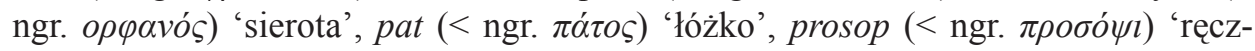
nik', saltea ( $<$ ngr. $\sigma \varepsilon \lambda \tau \bar{\varepsilon} \varsigma)$ 'materac', molimă $(<$ ngr. $\mu o ́ \lambda v \sigma \mu \alpha)$ 'zaraza', nostim $(<$ ngr.

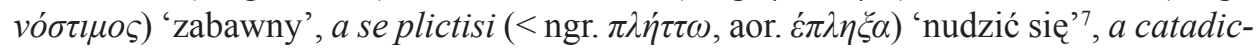
si $(<$ ngr. $\kappa \alpha \tau \alpha \delta \dot{z} \chi \rho \mu \alpha)$ 'raczyć'. Ponadto należy zauważyć, że zapożyczenia te funkcjonowały przede wszystkim w Mołdawii i na Wołoszczyźnie.

Pewne wyobrażenie na temat losów zapożyczeń greckich w rumuńskim daje poniższe zestawienie, z którego wynika, że odsetek słownictwa rumuńskiego pochodzenia greckiego spadł w ciagu jednego stulecia z ponad $10 \%$ do ok. $2 \%$.

\begin{tabular}{|l|c|c|c|}
\hline & $\begin{array}{c}\text { liczba analizowa- } \\
\text { nych wyrazów }\end{array}$ & $\begin{array}{c}\text { liczba } \\
\text { grecyzmów }\end{array}$ & procent grecyzmów \\
\hline język starorumuński $^{8}$ & 5750 & 650 & $11,3 \%$ \\
\hline język rumuński współczesny & & & \\
- całkowity zasób słownictwa $^{10}$ & 49642 & 1172 & $2,4 \%$ \\
- słownictwo reprezentatywne $^{10}$ & 2581 & 43 & $1,7 \%$ \\
\hline
\end{tabular}

Fala zapożyczeń rumuńskich z nowogreckiego dokonanych w epoce fanariockiej nie wytrzymuje jednak porównania z prawdziwym zalewem grecyzmów, jaki przeżył w ostatnich wiekach (a w Grecji ciagle przeżywa) język arumuński ${ }^{11}$. Wpływ nowogreckiego na leksykę arumuńską jest przemożny - dotyczy wszystkich części mowy, wszelkich odmian języka i najprzeróżniejszych pól leksykalnych. Dość powiedzieć,

${ }^{6}$ L. Gáldi, Les mots d'origine néogrecque en roumain à l'époque des phanariotes, Budapest 1939, s. 86.

${ }^{7}$ Chronologia zapożyczeń greckich w rumuńskim za: H. Mihăescu, op. cit. i V. Ilea-Pamfil, Influenţa greacă, w: Istoria limbii române, red. F. Dimitrescu, Bucureşti 1978, s. 102-108.

${ }^{8}$ Al. Cihac, Dictionnaire d'étymologie daco-romane, Frankfurt am Main-Berlin-Bucarest 1870 (t. I), 1879 (t. II), dane cyt. za: W. Mańczak, Języki romańskie, w: Języki indoeuropejskie, red. L. Bednarczuk, t. II, Warszawa 1988, s. 634.

${ }_{9}^{9}$ Analiza D. Macrei oparta na Dicționarul limbii romîne moderne, Bucureşti 1958.

10 M. Sala (red.), Vocabularul reprezentativ al limbilor romanice, Bucureşti 1988.

11 Do 1913 r. ekspozycja dialektów arumuńskich na wpływ grecki była dość wyrównana, z uwagi na to, że wszyscy ich użytkownicy zamieszkiwali w granicach jednego państwa - Imperium Osmańskiego. Po podziale Macedonii i powstaniu Albanii wpływ grecki na dialekty arumuńskie używane poza Grecją uległ zahamowaniu. 
że wszystkie wymienione wyżej zapożyczenia nowogreckie w rumuńskim występują również w arumuńskim, a oprócz nich funkcjonuje w nim ogromna liczba innych.

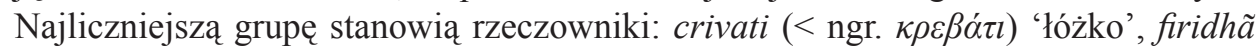

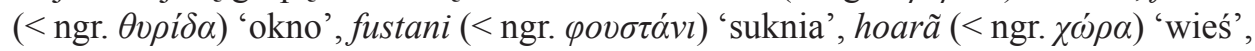
pisti (< ngr. $\pi i \sigma \tau \eta)$ 'wiara', sinidhisi (< ngr. $\sigma v v \varepsilon i \delta \eta \sigma \eta)$ 'świadomość' i czasowniki: apãndisescu (< ngr. $\alpha \pi \alpha v \tau \omega ́$, aor. $\alpha \pi \alpha ́ v \tau \eta \sigma \alpha)$ 'odpowiadam', mi efhãristisescu (< ngr. $\varepsilon v \chi \alpha \rho \imath \sigma \tau \omega$, aor. $\varepsilon v \chi \alpha \rho i ́ \sigma \tau \eta \sigma \alpha)$ 'dziękuję', alãxescu (< ngr. $\alpha \lambda \lambda \alpha \dot{\zeta} \omega$, aor. $\dot{\alpha} \lambda \lambda \alpha \xi \alpha)$ 'zmie-

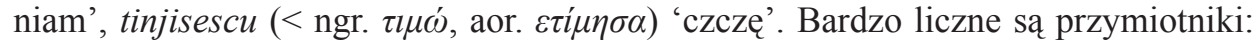

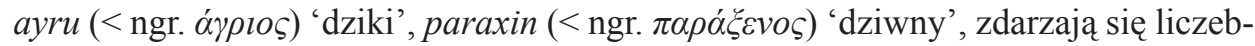

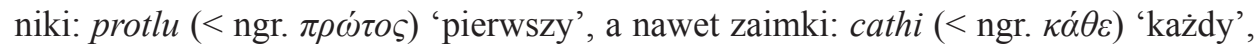

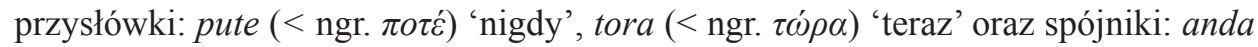
$(<$ ngr. $\alpha \dot{v} \tau)$ 'kiedy', $i(<$ gr. $\dot{\eta})$ 'lub'.

Porównując zapożyczenia nowogreckie w rumuńskim i arumuńskim warto zwrócić uwagę na ten sam mechanizm adaptacji czasowników: nie kontynuują one form czasu teraźniejszego, jak można by się tego spodziewać w związku z brakiem bezokolicznika, ale temat aorystu, dlatego jako etymon czasownika podajemy formę 1. osoby czasu teraźniejszego uważaną za formę słownikową oraz formę 1. osoby aorystu, od której pochodzi forma rumuńska lub arumuńska. Skutkiem tego jest specyficzny sufiks czasowników pochodzenia greckiego, rum. -(i)si (bezokolicznik), arum. -(i)se$s c u$, w którym -s-stanowi cechę greckiego aorystu:

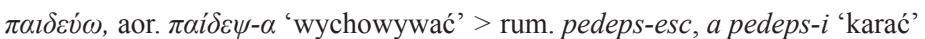

$\varepsilon v \chi \alpha \rho \imath \sigma \tau \omega ́$, aor. $\varepsilon v \chi \alpha \rho \imath \sigma \eta \dot{\eta} \sigma-\alpha$ 'dziękować' > arum. mi efhãristis-escu 'ts.'

Z kolei całościowe porównanie leksyki rumuńskiej i arumuńskiej pokazuje, że element grecki odgrywa w arumuńskim podobną rolę jak słowiański w rumuńskim, tzn. wypełnia luki leksykalne wynikające z braku odziedziczonego latynizmu bądź wypiera odziedziczone latynizmy, np. arum. lipseashti vs. rum. trebuie 'trzeba', arum. pirifan vs. rum. mândru 'dumny'. Niekiedy takie wyparcie nie jest całkowite i dochodzi do powstania par wyrazowych, początkowo tożsamych, a później zróżnicowanych semantycznie, np. arum. suflit (łac.), pnevmã (gr.), duh (słow.), rum. suflet (łac.), duh (słow.) 'dusza, duch'.

Jak się wydaje, takich przypadków jest więcej w arumuńskim niż w rumuńskim, co znaczy że stopień infiltracji arumuńskiego przez grekę jest większy niż rumuńskiego przez słowiański. Mamy zatem do czynienia z sytuacjami, w których w arumuńskim nie zachował się termin łaciński i używa sie jedynie grecyzmu, podczas gdy w rumuńskim wyraz łaciński się zachował, np. arum. irini (gr.) vs. rum. pace (łac.) 'pokój', arum. apãndisescu (gr.) vs. rum. răspund 'odpowiadam'. Jednocześnie w arumuńskim można wskazać szereg par dubletów łacińsko-greckich, którym w rumuńskim odpowiadają nie pary dubletowe łacińsko-słowiańskie, ale terminy wyłącznie łacińskie, np. arum. tser (łac.) - urano (gr.) vs. rum. cer (łac.) 'niebo’, arum. lea$d z i$ (łac.) - nom (gr.) vs. rum. lege (łac.) 'prawo', arum. ntãnjlu (łac.) - protlu (gr.) vs. rum. întâi, primul (łac.) 'pierwszy', rum. doilu (łac.) - dheftirlu (gr.) vs. rum. al 
doilea (łac.) 'drugi', arum. scri(esc)u (łac.) - (n)yrãpsescu (gr.) 'piszę', arum. rog, or (łac.) - pãrãcãlsescu (gr.) vs. rum. rog (łac.) 'proszę', arum. cred (łac.) - pistipsescu (gr.) vs. rum. cred (łac.) 'wierzę'.

Ponadto w przypadku rumuńskiego wpływ słowiański ma charakter jedynie historyczny, a udział zapożyczeń słowiańskich w leksyce rumuńskiej uległ w czasach reromanizacji znacznemu umniejszeniu, podczas gdy udział elementów greckich w leksyce arumuńskiej utrzymuje się na względnie stałym poziomie, a w Grecji wykazuje wręcz ciaggłą tendencję wzrostową. Oprócz tego grecki ciągle stanowi dla arumuńskiego źródło słownictwa abstrakcyjnego i terminologii specjalistycznej, podczas gdy w przypadku rumuńskiego słowiański utracił tę funkcję na rzecz francuskiego i łaciny. Paralelizm wpływu słowiańskiego na rumuński i greckiego na arumuński utrzymuje się jeszcze na poziomie terminologii religijnej: w rumuńskim jest ona w większości słowiańska (oraz grecko-słowiańska i grecka), a w arumuńskim głównie grecka. Np. celem oddania pojęć abstrakcyjnych z tekstu Ojcze nasz ('święcić się', 'wola', 'wina', 'pokuszenie'), które w językach zachodnioromańskich wyrażane są za pomocą zapożyczeń ze średniowiecznej łaciny (fr. se sanctifier, volonté, offense, tentation), rumuński ucieka się do cerkiewnosłowiańskiego (a se sfinți, voie, greşeală, ispită), zaś arumuński do greki (si ayiseashti, thelimã, steapsã, pirazmo $)^{12}$.

Poza leksyka, najbardziej podatną na obce wpływy, nawet w przypadku tylko pośredniego wpływu jednego języka na drugi, w warunkach częściowego lub całkowitego bilingwizmu wpływowi drugiego języka może ulec również struktura gramatyczna. Ponieważ bilingwizm romańsko-grecki dotyczy tylko Arumunów, od momentu zejścia na południe od linii Jirečka ${ }^{13}$ i osiedlenia się wśród ludności greckojęzycznej, skutki bilingwizmu dla struktury języka można wskazać głównie w odniesieniu do arumuńskiego.

Wpływowi greckiemu można przypisać przejście bałkanoromańskich [t]] i [d3] (pochodzących z palatalizacji łacińskich $[\mathrm{k}] \mathrm{i}[\mathrm{g}]$ przed samogłoskami przednimi) w [ts] i [dz], odróżniające arumuński (i meglenowołoski) od rumuńskiego ${ }^{14}$, np. rum. cer [t]er] 'niebo', ger [dzer] 'mróz', arum. i megl. tser, dzer 'ts.' Za grecką genezą tego swoistego bałkanoromańskiego „mazurzenia” czy greckim impulsem do niego przemawiałby brak szeregu szumiących w systemie greckim (nie licząc niektórych dialektów południowych ${ }^{15}$ ) i zastępowanie ich przez Greków w innych językach syczącymi. Arumuni, ucząc się greckiego, mieliby zatracić pod jego wpływem zdolność

12 Tekst Ojcze nasz za: C. Ucuta, Né $\Pi \alpha \_\delta \alpha \gamma \omega \gamma i \alpha$, Wien 1797.

${ }^{13}$ Linia oddzielająca w czasach rzymskich część greckojęzyczną Półwyspu Bałkańskiego od części łacińskojęzycznej. Jej przebieg ustalił Konstantin Jireček na podstawie inskrypcji greckich i łacińskich odkrytych na Bałkanach (K. Jireček, Geschichte der Serben, Gotha 1911).

$14 \mathrm{Jw}$., identyczna zmiana fonetyczna w południowym dialekcie istrowołoskiego jest dużo późniejsza (nb. nie zna jej dialekt północny) i zaszła pod wpływem tamtejszych gwar czakawskich (tzw. cakawizm), w których z kolei jest wynikiem wpływu weneckiego.

15 J. Reczek, Język nowogrecki, w: Języki indoeuropejskie, red. L. Bednarczuk, t. I, Warszawa 1986 s. 466. 
artykułowania spółgłosek szumiących. Problem w tym, że nie wszystkie arumuńskie [t]] i [d3] przeszły w [ts] i [dz] - te, które powstały z [tj] i [dj] przed [o], [u], np. ficior (< łac. *fetiolus) 'chłopak', agiut (< łac. adiuto) 'pomagam', jak również [d3] pochodzące z konsonantyzacji [j], np. giudic (< łac. judico) 'osądzam', zachowują się bez zmian. Ponadto slawizmy zawierające [t $\mathrm{t}]$ oraz późniejsze turcyzmy z [t $\left.\int\right]$ i [d3] zapożyczane zostały z zachowaniem swego oryginalnego brzmienia. W tej sytuacji należałoby uznać, że procesy $[\mathrm{tj}],[\mathrm{dj}] /[\mathrm{j}]>\left[\mathrm{t} \int\right],[\mathrm{d} 3]$ zaszły później niż zmiana $[\mathrm{k}],[\mathrm{g}]>$ $\left[\mathrm{t} \int\right],[\mathrm{d} 3]>[\mathrm{ts}],[\mathrm{dz}]$, w okresie wpływów słowiańskich ${ }^{16}$.

Pochodzenia greckiego jest najprawdopodobniej arumuńskie (i częściowo meglenowołoskie) przejście bałkanoromańskich dyftongów [aw], [ew] w połączenia [av], [ev] (przed spółgłoskami dźwięcznymi) lub [af], [ef] (przed spółgłoskami bezdźwięcznymi), w przeciwieństwie do rumuńskiego aud 'słyszę', caut 'szukam', preut (obecnie preot) 'ksiądz', arum. avdu, caftu, preftu 'ts.' ${ }^{17}$. Analogiczna zmiana objęła odpowiednie dyftongi greckie w okresie średniogreckim (XIII-XIV w.) ${ }^{18}$.

Ewidentnie greckie przekształcenie grup spółgłoskowych [nt], [nk], [mp] w [nd], [†g], [mb] objęło już tylko dialekty południowoarumuńskie, pozostające w bezpośrednim kontakcie z greką, np. alandu zamiast północnoarumuńskiego alantu 'inny', mãngare 'jedzenie' zamiast mãncare czy mblai zamiast mplai 'na górze'19.

Niewątpliwym wpływem greckim, w tym przypadku już na fonologię, jest wprowadzenie do arumuńskiego systemu fonologicznego trzech nowych fonemów, szczelinowych $/ ð /, / \theta /, / \gamma /$ (ten ostatni realizowany przed samogłoskami przednimi jako

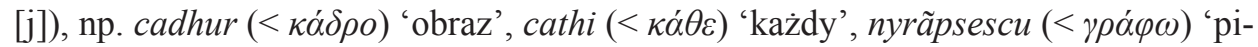
szę'. Weszły one do arumuńskiego wraz z zawierającymi je zapożyczeniami greckimi (choć /ð/ występuje również w zapożyczeniach z albańskiego). W dialektach Arumunów macedońskich i rumuńskich nowe fonemy uległy utożsamieniu z najbliższymi im fonetycznie zwartymi /d/20,/t/21 $/ \mathrm{g} /$, ze względu na słabe obciążenie funkcjonalne opozycji fonologicznych $/ ð / \sim / \mathrm{d} /, / \theta / \sim / \mathrm{t} /, / \gamma / \sim / \mathrm{g} /$. W dialektach Arumunów greckich odrębny status tych fonemów został utrzymany ze względu na ciagły wpływ grecki. Współczesna ortografia nie czyni rozróżnienia między zwartymi a szczelinowymi, choć dopuszcza pisownię $d h$, th i gh (lub y), jeśli występują one w dialekcie piszącego $^{22}$.

16 Przyjęcie takiej hipotezy oznaczałoby, że arumuński (być może z meglenowołoskim) stanowił odrębną grupę dialektalną (odmienny rozwój [k], [g] przed samogłoskami przednimi) już w okresie poprzedzającym kontakty romańsko-słowiańskie, co stawiałoby pod znakiem zapytania istnienie bałkanoromańskiej wspólnoty językowej lub przynajmniej jej postulowaną jedność.

17 Identyczna zmiana fonetyczna w istrowołoskim ma raczej charakter niezależny i pozostaje zapewne w związku z późniejszym wpływem języka chorwackiego, nieznającego połączeń dyftongicznych.

18 O. Jurewicz, Gramatyka historyczna języka greckiego, Warszawa 1999, s. 43-44.

19 Th. Capidan, Aromânii. Dialectul aromân, Bucureşti 1932, s. 195.

20 Niekiedy również ze szczelinowym /v/.

21 Czasami również ze szczelinowym /f/ lub /s/.

22 T. Cunia, Cursu di scriari armãneascã, dupã Regulili Astãsiti la Simpozionlu di Standardizari a Scriariljei Armãneascã di Bituli, Avgustu, 1997, s. 5-8. 
Pozostając przy kwestii alfabetu, należy dodać, że do pierwszych prób zapisu języka arumuńskiego użyto alfabetu greckiego. Zapisano w nim najstarsze zachowane zdanie po arumuńsku (1731 r.) i Liturgikon z mniej więcej tego samego okresu, wydrukowano dwa „leksykony”, tj. słowniki kilkujęzyczne (1770 i 1794) i abecadło (1797 r.) Constantina Ucuty, który podjął pierwszą poważną próbę konsekwentnego przystosowania alfabetu greckiego do potrzeb języka arumuńskiego. W tym czasie, w związku ze zburzeniem w 1769 r. Moskopola, kulturowego i ekonomicznego centrum Arumunów, arumuńskie elity intelektualne żyły już i działały w AustroWęgrzech, gdzie pod wpływem Szkoły Siedmiogrodzkiej zaczęły używać alfabetu łacińskiego. Mimo to, alfabet grecki używany jest do zapisu języka arumuńskiego również współcześnie, oczywiście tylko w Grecji i tylko doraźnie, w sposób nieustandaryzowany.

Wpływ grecki na arumuński przejawia się również we fleksji, która zapożyczyła dwie greckie końcówki liczby mnogiej. Pierwsza z nich, -adz, kontynuuje grec-

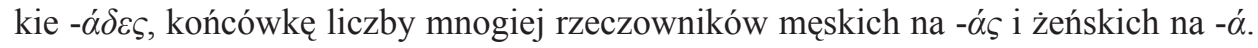
Przeszła do arumuńskiego razem z rzeczownikami typu $\alpha \mu \iota \rho \dot{\varsigma}$ 'król', zapożyczonym wraz z grecką liczbą mnogą $\alpha \mu \imath \rho \alpha ́ \delta \varepsilon \varsigma$, które to formy dały w arumuńskim odpowiednio amiră - amiradz. Wyabstrahowaną z takich rzeczowników końcówkę liczby mnogiej - $a d z$ rozszerzono następnie na inne rzeczowniki, głównie inne grecyzmy, ale także turcyzmy. Objęło to również wyrazy, które w nowogreckim należą do innych typów deklinacyjnych niż $\alpha \mu \imath \alpha \dot{\varsigma}-\alpha \mu \imath \rho \dot{\delta} \delta \varepsilon \varsigma$ i w związku z tym inaczej tworzą liczbę

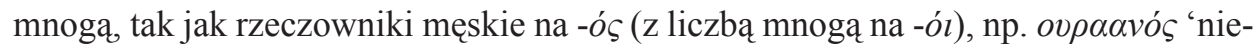

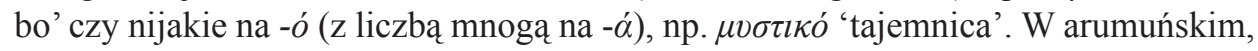
ze względu na brak rodzaju nijakiego ${ }^{23}$, są one rodzaju męskiego i przyjmują końcówkę -adz, np. urano - uranadz, mistico - misticadz, używaną zresztą tylko dla rodzaju męskiego (w greckim również dla żeńskiego). Do tego samego typu deklinacyjnego włączono zapożyczenia z tureckiego typu cafine ( $\mathrm{lm}$. cafineadz) 'kawiarnia' czy cafigiu ( $\mathrm{lm}$. cafigeadz) 'sprzedawca kawy'. Stworzenie nowego typu deklinacyjnego dla jednych i drugich zapożyczeń (wszystkie z akcentem oksytonicznym) uwarunkowane jest trudnościami z ich adaptacją do systemu arumuńskiego, w którym nie było wcześniej rzeczowników rodzaju męskiego z akcentem na ostatniej sylabie.

Druga z zapożyczonych końcówek, -ate (postać zredukowana, częsta u Arumunów greckich, brzmi -ati), w przeciwieństwie do pierwszej może występować jedynie z tymi rzeczownikami, dla których jest normalną końcówką liczby mnogiej również w nowogreckim. Greckie rzeczowniki nijakie na - $\alpha$ z końcówką liczby mnogiej $-\alpha \tau \alpha$, np. $\gamma \rho \alpha ́ \mu \alpha-\gamma \rho \alpha ́ \mu \alpha \tau \alpha$ 'litera', $\theta \alpha v ́ \mu \alpha-\theta \alpha \dot{\mu} \mu \alpha \tau \alpha$ 'cud', stają się na gruncie arumuńskim rzeczownikami żeńskimi (w związku z brakiem rodzaju nijakiego) tworzącymi nowy typ deklinacyjny $-\tilde{a}-1 \mathrm{~m}$. -ate ${ }^{24}$, np. ghramã - ghramati, thamã - thamati. Powstanie

${ }^{23}$ Rumuńskie i arumuńskie rzeczowniki nijakie są właściwie rzeczownikami zmiennorodzajowymi: męskimi w liczbie pojedynczej i żeńskimi w mnogiej.

${ }^{24}$ Końcowe -el-i jest wynikiem wpływu rodzimej końcówki liczby mnogiej rzeczowników rodzaju żeńskiego -e (postać zredukowana: -i). 
tego typu nie jest do końca jasne, ponieważ powyższe rzeczowniki, zaadaptowane jako żeńskie, mogły zostać włączone do dominującego typu odmiany żeńskiej na - $\tilde{a}-$ lm. -e (postać zredukowana: $-i$ ) - tak zresztą stało się z rzeczownikiem thamã , posiadającym oboczną do podanej wyżej formę liczby mnogiej thame/thami. Ponadto końcówka -ate/-ati występuje jedynie we fleksji rzeczownikowej, podczas gdy -adz może być również końcówką liczby mnogiej rodzaju męskiego przymiotników ${ }^{25}$.

W arumuńskim występuje również szereg prefiksów i sufiksów słowotwórczych pochodzenia greckiego. Pewną produktywność wykazują prefiksy: andi $(<$ gr. $\alpha v \tau i)$, np. stau 'stoję' > andistau 'stoję naprzeciw, sprzeciwiam się', apu (< gr. $\alpha \pi o ́), n$ p.

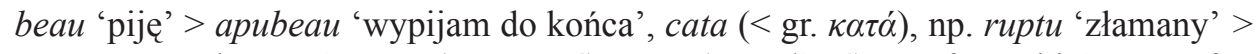
cataruptu 'połamany', mata (< gr. $\mu \varepsilon \tau \alpha ́)$, xana (< gr. $\zeta \alpha v \alpha ́)$, np. fac 'robię'> matafac, xanafac 'robię znów', para (< gr. $\pi \alpha \rho \alpha ́)$, np. fac > parafac 'robię za dużo' oraz sufik-

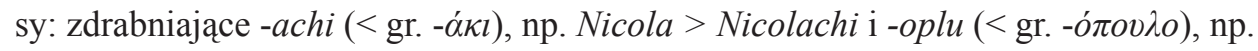

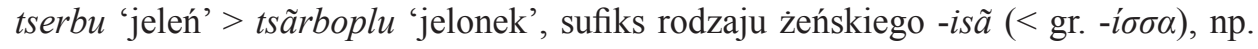
drac 'diabel' $>$ dracsã 'diablica', sufiks tworzący nazwy mieszkańców $-(i)$ ot $(<$ gr. $\imath \omega ́ \tau \iota \varsigma)$, np. Samarina $>$ sãmãrnjot 'mieszkaniec Samariny', sufiksy tworzące rzeczow-

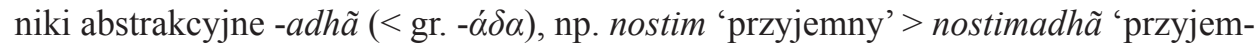
ność' i -izmã (< gr. $i \zeta \zeta \alpha)$, np. mi aspar 'przerazić się'> asparizmã 'przerażenie', sufiks rzeczowników kolektywnych -ario (< gr. $\alpha \rho \varepsilon i o ́)$, np. porcu 'świnia' > purcario

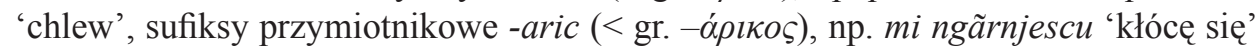
$>$ ngãrnjaric 'kłótliwy' i -itic (< gr. -ítıkos), np. tc. soylu 'szlachetny'> suilitic 'ts.' oraz sufiks przysłówkowy $-a(<$ gr. $-\alpha$ ) $)$, np. adãnc 'głęboki' > adãnca 'głęboko'26. Spośród powyższych rumuński zna tylko jeden: sufiks zdrabniający -ache (< gr. óki), mało zresztą produktywny, np. cuțu 'szczenię'> cuțulache 'szczeniaczek'. Być może pochodzenia greckiego jest wspólny dla arumuńskiego i rumuńskiego (choć również bardzo rzadki) sufiks -andru (wyabstrahowany zapewne z imion ${ }^{27}$ typu Alexandru < gr. $A \lambda \dot{\varepsilon} \xi \alpha v \delta \rho o \varsigma)$, np. rum. cățel 'szczenię' > cățelandru 'szczeniak', arum. hilju 'syn' $>$ hilandru 'chłopak'. O wiele bardziej produktywny jest w obu językach sufiks -ie (gr. -í $\alpha$ ), lecz może być on równie dobrze odziedziczony z łaciny lub zapożyczony ze słowiańskiego.

W odniesieniu do wpływów greckich na składnię można wreszcie mówić o zjawiskach wspólnych dla rumuńskiego i arumuńskiego, mimo że ich zasięg jest różny. Mają one charakter ogólnobałkański i należą do tzw. bałkanizmów, jednak przynajmniej część z nich może być pochodzenia greckiego. O greckie pochodzenie podejrzewać można takie bałkańskie cechy, jak zanik bezokolicznika i jego zastąienie trybem łączącym oraz słowo posiłkowe o semantyzmie 'chcieć' jako składnik peryfrastycznego czasu przyszłego ${ }^{28}$. Alternatywne teorie przypisują tym innowacjom

${ }^{25}$ M. Caragiu-Marioțeanu, Fono-morfologie aromână. Studiu de dialectologie structurală, Bucureşti 1968, 96-97.

26 Th. Capidan, op. cit., s. 512-520

${ }^{27}$ H. Misterski, Sufiksacja w języku rumuńskim, Poznań 1987, s. 40.

28 Teorię o greckim pochodzeniu wszystkich bałkanizmów morfosyntaktycznych (poza rodzajnikiem postpozycyjnym, nieistniejącym w grece) lansował Kristian Sandfeld (Linguistique balkanique : 
pochodzenie paleobałkańskie, ze względu na ich obecność w albańskim ${ }^{29}$. Problem pozostaje nierozstrzygnięty i w tym miejscu pozostaje nam jedynie wskazać na możliwość wpływu greckiego również w tym zakresie. Tak czy inaczej, oba zjawiska są w rumuńskim i arumuńskim pochodzenia obcego, gdyż nie zna ich ani łacina, ani romańszczyzna pozabałkańska. Tendencja do zastępowania bezokolicznika trybem łączącym w rumuńskim została jednak w pewnym stopniu zahamowana. W niektórych sytuacjach użycie bezokolicznika jest ciagle opcjonalne, jak po czasowniku modalnym a putea 'móc', np. pot să spun (z trybem łączącym) = pot spune (z bezokolicznikiem) 'mogę powiedzieć'. W arumuńskim używa się już wyłącznie trybu łączącego, np. pot si-aspun 'mogę powiedzieć'. Podobnie wygląda kwestia czasu przyszłego $\mathrm{z}$ 'chcieć'. W rumuńskim stosowany jest on wymiennie z romańskim z pochodzenia czasem przyszłym z czasownikiem posiłkowym 'mieć', np. voi spune lub o să spun (z 'chcieć') vs. am să spun (z 'mieć') 'powiem'. W arumuńskim istnieje tylko czas przyszły oparty na 'chcieć', va si-aspun 'ts.'. W rumuńskim panuje zatem sytuacja przejściowa, dopuszczająca opcjonalność użyć, podczas gdy arumuński w obu przypadkach zachowuje się dokładnie tak samo jak nowogrecki, który zna jedynie konstrukcje typu: $\mu \pi о \rho \dot{~} v \alpha \pi \omega^{\prime}$ 'mogę powiedzieć' (z trybem łączącym zamiast bezoko-

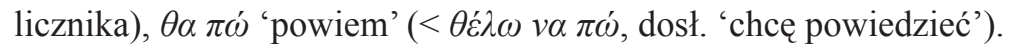

Zjawiskiem o genezie niewątpliwie greckiej jest za to możliwość zastąpienia zaimka dzierżawczego przymiotnego nieakcentowaną formą zaimka osobowego w dopełniaczo-celowniku. Taka wariantywność występowała w starogreckim, np. (ó) $\dot{\varepsilon} \mu o ̀ s$

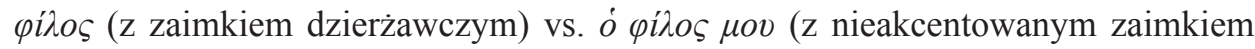
osobowym w dopełniaczu ${ }^{30}$, podczas gdy w nowogreckim dzierżawczość w tego typu konstrukcjach wyrażana jest już tylko klityką zaimka osobowego w dopełnia-

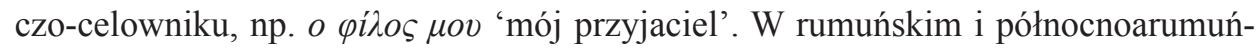
skim, mimo że normalnie używa się zaimka dzierżawczego, dopuszczalne jest użycie w tej funkcji klityki zaimka osobowego, choć jest to zabieg stosowany niemal wyłącznie w literaturze, głównie w poezji, dla potrzeb rymu i rytmu, np.

rum.

Aducerile-aminte pe suflet cad in picuri,

Redeşteptând în fạță-mi trecutele nimicuri;

$\mathrm{Cu}$ degetele-i vântul loveşte în ferești,

Se toarce-n gându-mi firul duioaselor povești.

(Departe sunt de tine, Mihai Eminescu)

problèmes et résultats, Paris 1930). W nieco ograniczonym zakresie, w odniesieniu właśnie do zaniku bezokolicznika i budowy czasu przyszłego, przejął ją m. in. Adam Weinsberg (Językoznawstwo ogólne, Warszawa 1983, s. 79).

${ }^{29}$ Hipotezę o substratowym pochodzeniu bałkanizmów morfosyntaktycznych wysunął ojciec bałkanistyki, Jernej Kopitar (Albanische, walachische u. bulgarische Sprache, „Jahrbücher der Literatur”, Wien 1829, s. 46, 59-106). Obecnie próbuje ją udowodnić zespół badaczy FWF Austrian Science Fund (http://www.fwf.ac.at/en/public_relations/press/pv200805-en.html, dostęp: 13.11.2012).

${ }^{30}$ M. Auerbach, M. Golias, Gramatyka grecka, Warszawa 2000, s. 122-123. 
arum.

Tu somnu-nji apitrusit di yisi,

Pisupra-a suflitlu-nji nvirinat,

S-azvimturã nicurmat pirmisi,

Dit-chirolu di-anda io-fui amintat.

(Tu somnu-nji, Dumitru Piceava)

W powyższych fragmentach zamiast oczekiwanych form fața mea 'moja twarz', degetele lui 'jego palce', gândul meu 'moja myśl' (rum.) czy somnul a meu 'mój sen', suflitlu a meu 'moja dusza' (arum.) użyto odpowiednio: față-mi, degetele-i, gându-mi i somnu-nj, suflitlu-nj, dosłownie 'twarz mi', 'palce mu', 'myśl mi' i 'sen mi', 'dusza mi'. Formy należące do pierwszej serii były najwyraźniej za długie, stąd zastąpiono je obocznymi formami z drugiej serii, wygodniejszymi, bo krótszymi i łatwiej komponującymi się rytmicznie z resztą tekstu. Regularny charakter ma za to użycie enklityk zaimka osobowego w funkcji dzierżawczej w południowoarumuńskim, w greckim otoczeniu językowym, co dodatkowo świadczy o greckiej genezie zjawiska ${ }^{31}$.

Obok kalk składniowych z greki wskazać można szereg kalk na poziomie uzusu

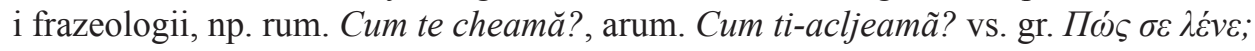
'Jak się nazywasz?' Mimo że paralelna konstrukcja występuje we włoskim (Come ti chiami?), czyli w innym języku romańskim, jej odpowiedniki w rumuńskim i arumuńskim należy uważać za kalki z greckiego, w którym również dla wszystkich osób używa się czasownika w 3 . osobie liczby mnogiej32. Inne przykłady: rum. Ce faci?,

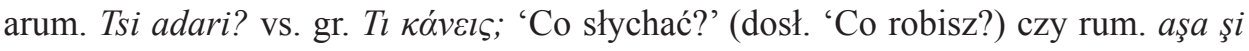

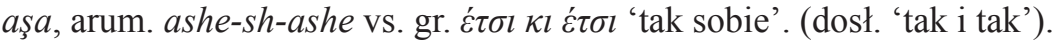

Analiza języków: rumuńskiego i arumuńskiego pod kątem wpływu, jaki wywarł na nie język grecki, prowadzi do wniosku, że skutki jakościowe i ilościowe tego oddziaływania przedstawiają się dla każdego z nich zgoła inaczej. Liczba grecyzmów w rumuńskim, mimo że znaczna w okresie średniowiecza i w pierwszych wiekach epoki nowożytnej, jest we współczesnym języku wręcz marginalna. W arumuńskim z kolei słownictwo pochodzenia greckiego stanowi integralną część leksyki, pozwalając nierzadko na wyrażanie podstawowych pojęć, nie mówiąc już o tych o wyższym stopniu abstrakcji i specjalizacji. Również oddziaływanie greki na strukturę gramatyczną romańszczyzny bałkańskiej jest bardziej konsekwentne w przypadku arumuńskiego niż rumuńskiego. Pozwala to na potraktowanie elementów greckich w arumuńskim jako adstratu najważniejszego jakościowo i ilościowo, podczas gdy w odniesieniu do rumuńskiego można mówić jedynie o kolejnym adstracie o znikomym obecnie znaczeniu.

${ }^{31}$ Th. Capidan, op. cit., s. 195.

${ }^{32} \mathrm{~W}$ istrowołoskim czasownik uzgadniany jest z odpowiednią osobą, a zaimek ma charakter zwrotny, a nie osobowy, co odpowiada dokładnie konstrukcji włoskiej, lecz jest dodatkowo wzmocnione wpływem chorwackim. 


\title{
GREEK HERITAGE IN ROMANIAN AND AROMANIAN
}

\begin{abstract}
Summary
This paper analyses the Greek influence upon two major Balkan Romance languages, Romanian and Aromanian (the most affected, as it seems, by this influence, historically, like Romanian, and also contemporarily, like Aromanian). In Romanian, for the period of the strongest Greek impact, the Greek lexicon is estimated to be over $10 \%$, but in the contemporary language, the words of Greek origin represent only $2 \%$. In Aromanian, due to its constant contact with Modern Greek (especially in Greece), Greek borrowings are extremely common, expressing not only abstract and specialized terminology, but also many notions of everyday life. Besides the Greek elements in Romanian and Aromanian vocabulary, we notice a number of phonetic, phonological, morphological and syntactic features of Greek origin, either obvious or potential. They appear especially in Aromanian, which borrowed some Greek phonemes and morphemes (both inflectional and derivational) and also adopted, more constantly than Romanian, some syntactic constructions, possibly of Greek origin.
\end{abstract}

